\title{
CONFLITOS ÉTICOS E MAGISTÉRIO DA IGREJA
}

\author{
Ethical conflicts and Magisterium of the Church
}

\author{
Eduardo López Azpitarte*
}

RESUMO: O magistério da Igreja tem a responsabilidade de ensinar e zelar pelo bem dos membros da comunidade eclesial. No campo da teologia moral, historicamente tem havido tensões e dissensos entre a autoridade eclesiástica e teólogos e cristãos que desejam se explicitem as razões das normas que lhe são impostas. Posições diversas sobre que esta questão mostram, entre outras urgências, a necessidade de se passar da submissão à palavra da autoridade, por medo, para a autonomia respeitosa que inclui a racionalidade das normas morais. Do contrário, se caminharia para a formação de uma consciência autoritária. Na busca de crescimento nessas relações os cristãos que ousam manifestar seu dissentimento ante o magistério contribuem para o avanço da formulação da doutrina moral católica. No processo vital da experiência eclesial, as tensões nascidas do esforço do desejo de compreensão racional da moral podem ajudar tanto o magistério quanto os teólogos no exercício das respectivas funções, por meio do diálogo verdadeiro.

Palavras-Chave: Autoridade, Magistério, Moral, Consciência, Diálogo.

ABSTRACT: The Magisterium of the Church has a responsibility to teach and care for the good of the members of the Church community. In the field of moral theology, historically there has been tension and dissent among the ecclesiastical authority and theologians and Christians who want to more clearly define the reasons of the standards that are imposed. Diverse positions on this issue show, among other urgencies, the need to move from the submission to the word of authority, out of fear, to respectful autonomy that includes the rationality of moral norms. Otherwise, the tendency would be toward the formation of an authoritarian consciousness. In search of growth in these relationships the Christians who dare to express their voice against teaching contribute to the advancement of formulation of Catholic moral doctrine. In the vital process of ecclesial experience, the tensions

\footnotetext{
* Faculdade de Teologia de Granada - Espanha. Artigo submetido a avaliação em 06.08.2012 e aprovado para publicação em 20.09.2012.
} 
born of the effort in the desire of rational understanding of morality can help both the Magisterium and the theologians in the performance of their respective duties, by means of truthful dialogue.

KEYwORDS: Authority, Magisterium, Morals, Conscience, Dialogue.

\section{As tensões inevitáveis na Igreja}

$\mathrm{N}$ enhum católico sério se atreveria a negar o valor que tem o Magistério da Igreja. Como sacramento de salvação, ela visa conservar intacta a palavra de Deus e transmitir fielmente a seus fiéis a mensagem de Jesus. "A tarefa de interpretar autenticamente a palavra de Deus, escrita ou transmitida, foi confiada exclusivamente ao Magistério vivo da Igreja, cuja autoridade é exercida em nome de Jesus" ${ }^{\prime 1}$. É evidente que em seu ensino, além dos aspectos relacionados com a fé, incluem-se, também, aquelas práticas e costumes que vão contra os dados da revelação. Como em toda instituição, deve-se limitar as fronteiras para saber quem faz parte dela, ou quem se encontra em áreas marginais.

Além disso, faz algum tempo que algumas igrejas protestantes lamentaram a falta de normas e orientações, visto que a exclusiva responsabilidade pessoal não está livre de perigo. E há, além disso, o risco de um pluralismo excessivo e contraditório, mas sem cair, como se afirma em algum documento, na "via legalista e autoritária do magistério católico" 2 .

A aceitação da doutrina católica não eliminou, sem dúvida, as inevitáveis tensões que sempre existiram ao longo da história. Já faz alguns anos que a Comissão Teológica Internacional publicou um documento sobre a relação entre a teologia e o magistério, onde falava da inevitável tensão entre essas funções. A autoridade desta Comissão impede catalogar este fenômeno como ato de rebeldia ou como um gesto de falta de amor em relação à instituição eclesial. Valoriza-o, em primeiro lugar, como um fato que não tem nada de anormal ou extraordinário: "não é estranho nem se deve esperar que se possa solucionar uma vez por toda nesta terra". E o considera, além disso, como algo positivo e enriquecedor, "visto que não supõe inimizade ou autêntica oposição, mas um esforço vital e estímulo para cumprir juntos, em forma de diálogo, o próprio ofício de cada um"3.

\footnotetext{
${ }^{1}$ Constituição Dogmática sobre a Divina Revelação, n. 10.

${ }^{2}$ Assim, por exemplo, COMISSIONE SINODALE DI STUDIO. La sessualitá nella Bibbia nel tempo presente, Torino 1984, p. 3. GESTEIRA GRAZA, M. "La autoridad magisterial de la Iglesia a la luz del diálogo ecuménico". Micelánea Comillas, v. 59, n. 115, juliodiciembre, p. 431-456, 2001.

3 "Theses de Magisterii ecclesiastici et Theologiae ad invicem relatione". Documenta (1969-1985), Editrice Vaticana: Roma 1988, p. 136. Cf., além do breve, mas realista comentário que em seguida se insere, p. 155, Também NOVO CID-FUENTES, A. J. "EL
} 
A última Instrução sobre este tema repete a mesma ideia: "se as tensões não brotam de um sentimento de hostilidade e de oposição, podem apresentar um fator de dinamismo e um estímulo que incita o Magistério e os teólogos a cumprir suas respectivas funções praticando o diálogo" ${ }^{\prime 4}$.

Aqui poder-se-ia aplicar, também, o que o próprio K. Wojtyla afirmava da oposição solidária e comprometida com o bem comum: "Aquele que proclama sua oposição, nem por isso recusa sua condição de membro da comunidade... Pelo contrário, busca seu próprio lugar dentro da comunidade, busca uma participação e atitude em direção ao bem comum que lhe permitiria conseguir uma participação melhor, mais completa e mais efetiva na comunidade" ${ }^{\prime \prime}$.

Embora existam razões psicológicas, sociais e religiosas para insistir na obediência como um valor importante, semelhante atitude não elimina situações conflituosas. Se as relações tivessem sempre seguido por um único caminho de submissão, uma pacífica harmonia reinaria sempre, sem as inquietações que ameaçam sempre a convivência humana, quando entram em jogo novas perspectivas. Na vida da Igreja, como em qualquer comunidade humana, houve oscilações significativas ao longo da história. Épocas nas quais se manteve uma coesão profunda, sem feridas traumáticas e outras nas quais a divisão, a desconfiança mútua, a suspeita, a condenação ou a rebeldia se manifestam com maior facilidade.

No momento atual, muitos estarão de acordo em que os vínculos da autoridade com seus subordinados não são de todo pacíficos. Agora me deterei exclusivamente nas dificuldades que hoje se constatam no campo concreto da moral. Acredito que existem algumas peculiaridades específicas, que não se dão no âmbito da Escritura ou da Dogmática, e que exigem, portanto, uma abordagem um pouco diferente. Vou me deter, fundamentalmente, sobre alguns fatores que condicionam a existência destes possíveis conflitos.

\section{A superação de enfoques antigos}

Sempre me neguei a reconhecer a diferença clássica que se admitia entre ética e moral. Era um enfoque que aparecia nas primeiras páginas dos textos de Teologia Moral, a começar dos mais clássicos até alguns dos mais

magistério en la Iglesia". Lumieira, n. 60 p. 65-68, 2007. BRIGHENTI, A. "Iglesia, teología y magisterio en Latinoamerica. Enfrentamientos innecesarios y tensiones evitables". Concilium, n. 345, p. 45-58, 2012.

${ }^{4}$ Veja a instrução da CONGREGAÇÃO PARA A DOUTRINA DA FÉ. La vocación eclesial del teólogo, v. 25. Ecclesia, n. 2483, p. 20-30, 1990.

${ }^{5}$ WOJTYLA, K. Persona y acción. BAC: Madrid 1982, p. 334. 
recentes ${ }^{6}$. A ética se fundamentava exclusivamente na razão humana, com seus limites e incapacidades; enquanto a moral se apoiava na palavra de Deus, como a Igreja a propunha em seus ensinamentos. A ética, como disciplina filosófica, era somente uma ancilla Theologiae (escrava da teologia) que não pode se tornar independente da fé. Também, nos documentos recentes do magistério está explícita, com maior ou menor ênfase, esta mesma ideia de que sem a fé não é possível conhecer completamente as verdades éticas. "O homem pode reconhecer o bem e o mal que ele mesmo realiza mediante sua razão iluminada pela Revelação divina e pela fé" 7 .

As consequências deste enfoque resultavam demolidoras, visto que se argumentava que as exigências éticas se apoiam fundamentalmente nas crenças religiosas. A seguinte citação é uma dentre outras possíveis: "As proposições da ética devem ter o mesmo rigor, coerência e justificação que as proposições científicas. Ao contrário disso, os princípios, normas ou juízos de uma determinada moral não se revestem desse caráter. E não só não têm um caráter científico, senão que a experiência histórica moral demonstra que muitas vezes são incompatíveis com os conhecimentos que trazem as ciências naturais e sociais. Portanto, podemos afirmar que se se pode falar de uma ética científica, não se pode dizer o mesmo da moral. Não há uma moral científica" ${ }^{\prime \prime}$.

Embora hoje muitos autores continuem aceitando uma distinção entre as duas disciplinas, sua interpretação é bastante diferente e não haveria dificuldade em admiti-la, apesar de não se considerar a origem histórica destes vocábulos. Sem entrar agora em mais detalhes, a moral faria referência ao conjunto das normas que orientam a vida, enquanto a ética estudaria racionalmente a justificação das condutas.

De qualquer modo, depois de tudo o que foi dito, acredito que as exigências éticas ou morais terão uma fundamentação razoável. Vivemos em uma sociedade que tem consciência de ter alcançado sua maioridade e deseja ter uma justificativa sensata do porquê tem que se comportar e atuar desse ou daquele modo.

\footnotetext{
${ }^{6}$ Como exemplo da postura tradicional, conservada constantemente, podemos consultar: VERMEERSCH, A. Theologia Moralis. Gregoriana: Roma, 1933, p. 9. Entre os mais recentes: FERNÁNDEZ, A. Diccionario de Teología Moral. Monte Carmelo: Burgos 2005, p. 909-912.

${ }^{7}$ JUAN PABLO II. Encíclicas. "El esplendor de la verdad", n. 44 (a cursiva encontra-se no original); "El valor inviolable de la vida humana", 71 y 72; "Sobre las relaciones entre fe y razón", n. 85, etc.

${ }^{8}$ SÁNCHEZ VÁZQUEZ, A. Ética. Barcelona: Editorial Critica, 1981, p. 25-26.
} 


\section{Da submissão à autonomia}

Eu sempre critiquei a existência de uma moral infantil tão frequente na práxis cristã, que sabe muito bem o que se tem a fazer, entretanto ignora e desconhece as razões desse comportamento. É a dificuldade atual de muitos padres e mestres que se sentem incapazes de dar uma explicação razoável às novas perguntas que lhes são feitas ${ }^{9}$. A eticidade de uma conduta não se radica na revelação de Deus ou no ensino da Igreja. A autoridade, fora a legislação positiva, não pode ser nunca o argumento definitivo para provar a malícia de uma ação. Isto significa que a normativa ética não pode ter outro ponto de partida que a racionalidade da própria conduta. A tradição, o magistério da Igreja, a mesma palavra de Deus deve ser uma fonte de dados importantes para se tomar qualquer decisão posterior a mais honesta e objetiva possível. No entanto, uma coisa é a ajuda para evitar potenciais erros e subjetivismos exagerados, e, outra coisa, muito diferente, é aceitar a licitude ou imoralidade de uma conduta pelo fato de ser ordenada ou proibida.

Todos os autores que trataram sobre o desenvolvimento do sentido moral insistem em que esta autonomia, ainda que se designe de diferentes modos, é a meta de todo processo educativo: que o indivíduo esteja convencido do modo e do porquê tem que agir ${ }^{10}$. A própria abordagem de Santo Tomás, quando fala da ofensa a Deus, é extraordinariamente moderna: “Deus não se sente ofendido por nós a não ser porque agimos contra nosso próprio bem"11. Isto significa que, quando alguém se considera incorreto ou pecaminoso, todo ser humano tem o direito em pedir uma explicação para que possa agir a partir de uma convicção pessoal e não pelo simples fato de ter sido mandado. Santo Tomás volta a nos recordar que "aquele que evita o mal não por ser mal, senão por ser mandado, não é livre, mas aquele que o evita por ser um mal, esse é livre"12.

Dito de outro modo, não se pode apresentar uma doutrina como ética e exigir uma submissão sem argumentos racionais. Por fé aceitamos uma série de verdades que não se explicam com justificativas humanas, senão pela autoridade de Deus que se revela, mas as obrigações éticas não per-

${ }^{9}$ Cf. LÓPEZ AZPITARTE, E. Fundamentação da ética cristã. São Paulo: Paulus, 1995, p. 87-110. "La educación moral en la família", Revista Agustiniana, v. 36, p. 503-535, 1995. Hacia una nueva visión de ética cristiana. Santander: Sal Terrae, p. 86-110, 2003. ${ }^{10}$ Cf. QUINTANA CABANAS, J. M. Pedagogia moral. El desarrollo moral integral. Dykinson: Madrid 1995. E a magnifica reflexão de VALADIER, Paul. Un cristianismo de futuro. Por una nueva alianza entre razón y fe, PPC: Madrid 2001. Também TORRES QUEIRUGA, A. "Moral y religión: de la moral religiosa a la visión religiosa de la moral". Selecciones de Teología, v. 44, n. 174, p. 83-92, abr./jun., 2005.

${ }^{11}$ Summa contra gentes III, 122.

${ }^{12}$ In epistolam ad Corinthios, cap. III, lect. III. In: Opera Omnia, t. 21, Vivès: Paris 1876, p. 62 . 
tencem a esse mundo de mistérios. É verdade que a confiança na autoridade é suficiente para os que não conhecem nem desejam saber as razões que existem, porém essa mesma autoridade tem que estar capacitada para dar uma justificativa razoável sempre que alguém a solicite.

Não acredito que exagere muito se sublinho o valor excessivo que tiveram os argumentos de autoridade. Desde pequeno nos ensinaram com toda exatidão como devia ser nosso comportamento, mas apenas preocupavamse em dar uma explicação razoável do por que se deve agir de tal maneira. No fundo, ficava sempre uma motivação oculta, mas muito eficaz: era uma condição indispensável para se obter o carinho insubstituível de nossos pais, a estima e o apreço das pessoas que nos rodeavam e, sobretudo, a amizade com Deus que, como crentes, resultava ainda mais importante. Uma fundamentação muito heterônoma, baseada, sobretudo, no medo em perder o afeto e o carinho dos demais.

\section{O risco de uma consciência autoritária}

Tudo isto explica porque se forma com toda facilidade uma consciência autoritária, como um mecanismo espontâneo do psiquismo humano. $\mathrm{O}$ aspecto mais característico reside no fato de que suas determinações e imperativos não nascem a partir de um juízo de valor sobre a conduta, por uma conviç̧ão racional de que assim se deve comportar, senão por ser simplesmente mandados da autoridade. A educação, como alguns criticaram, seria uma espécie de chantagem afetiva para manter um controle sobre as condutas alheias; um autoritarismo que impede o processo de formas de autonomia indispensáveis para a maturidade pessoal. Não duvido que estas etapas estão vinculadas à nossa psicologia. O lamentável é que este processo que deveria ser uma etapa passageira, estabiliza-se de forma permanente. São muitos os que vivem com uma consciência manipulada e ignorantes desta situação, visto que resulta muito mais cômodo e tranquilizador permanecer assim do que enfrentar a própria autonomia e responsabilidade ${ }^{13}$.

O que é mais perigoso nesta situação é que a autoridade termina, fazendose anônima e, se não se converte o indivíduo em um autêntico escravo, faz dele um autômato que se deixa levar pelo conformismo. As reflexões de Fromm, para explicar a gênese desta estrutura no âmbito sociológico e

\footnotetext{
${ }^{13}$ MARDONES, J. M. “Existe también una manipulación religiosa?”. Santander: Sal Terrae, v. 72, n. 7-8, p. 521-536, 1984. GARCIA-MONGE, J. A. "Psicología de la sumisión y psicología de la responsabilidad en la Iglesia”. Sal Terrae, Santander, v. 84, n. 296, p. 21-34, enero 1996. ARRIETA, Lola. "El poder en la Iglesia ¿Poder para dominar o para servir y liberar?. Sal Terrae, v. 84, n. 296, p. 35-51, 1996. BEINERT, W. "Diálogo y obediencia en la Iglesia". Selecciones de Teología, v. 39, n. 153, p. 61-70, enero-marzo 2000 .
} 
político, são aplicáveis também ao mundo psicológico ${ }^{14}$. Em qualquer hipótese, a subordinação está mantida não por motivações racionais, senão por influxos, muitas vezes inconscientes, do mundo afetivo. Os sentimentos de medo, admiração ou carinho fazem que o subalterno renuncie a pedir explicações e se entregue sem dúvida à vontade daquele que decide.

Esta mentalidade ficou bastante marcada em uma encíclica de Pio X quando afirmava que "a Igreja é por sua natureza uma sociedade desigual; compreende duas categorias de pessoas: os pastores e a grei... só a hierarquia move e dirige... O dever da grei é aceitar ser governada... Enquanto o povo não tem outra saída que deixar-se conduzir e seguir docilmente a seus pastores"15. Para oferecer uma segurança maior que fomentara uma atitude de docilidade, recordou-se sempre, sem que agora pretendamos negar essa ajuda, a assistência especial do Espírito para evitar o erro nos ensinamentos da Igreja.

Há que se reconhecer, sem dúvida, como já disse, que hoje vivemos em uma sociedade onde se respiram outros valores diferentes. A Igreja não é uma democracia, certamente; no entanto, da mesma maneira que incorporou em outros tempos elementos muito significativos da sociedade monárquica, como a forma mais adequada de governo, também hoje poderia recolher certos aspectos da nossa cultural atual que não vê com bons olhos uma autoridade absoluta. Ainda que alguns teólogos pretendam o contrário, o papado não deveria se considerar com os atributos de uma monarquia absoluta. A igualdade dos batizados diante de Deus, que com tanta força se proclama, deveria se expressar, também, em sua própria estrutura, sem desprezar ninguém de sua inspiração evangélica ${ }^{16}$.

\footnotetext{
${ }^{14}$ Vale a pena ler FROMM, E. El miedo a la libertad. Martínez de Murguía: Madrid, 1977, especialmente a análise sobre a consciência autoritária em Ética y psicoanálisis. Fondo de Cultura Económica: México 1971, p. 157-172. ROVALETTI, M. "Consciencia y autoridad en el pensamiento de Erich Fromm". Revista Internacional de Sociología, v. 44, p. 547-561, 1986. GARCÍA COLLADO, M ${ }^{\mathrm{a}} \mathrm{J}$. "Falseamiento de la libertad y la obediencia". Sal Terrae, v. 78, n. 4, p. 303-309, abril 1990.

${ }_{15}$ Pio X, encíclica Vehementer nos de 11-II- 1906. Pode-se consultar em AA. VV., Nueva Historia de la Iglesia. Cristiandad: Madrid 1977, v. V, p. 146, já que desapareceu das últimas edições do DENZINGER-SCHÖNMETZER.

${ }^{16}$ SEIBEL, W. “¿Es la democracia ajena al ser de la Iglesia?”, Selecciones de Teología, n. 35, n. 139, p. 173-174, julio-septiembre 1996. HEINZ, H. "Democracia en la Iglesia. Corresponsabilidad y participación de todos los bautizados", Selecciones de Teología, n. 35 , n. 139 , p. $163-172,1996$. ESTRADA, J. A. "De la sociedad desigual a la comunidad de bautizados", e também: TORRES QUEIRUGA, A. "Magisterio, teología y pueblo". In: AA. VV., Retos de la Iglesia ante el nuevo milenio, Fundación Santa Maria: Madrid, 2001, 45-68 y 99-135. MAIER, H. ¿Democracia en la Iglesia?, San Pablo: Madrid, 2005. ROSHWALD, M. "Raíces bíblicas de la democracia", Selecciones de Teología, n. 47, p. 227-240, 2008. VALADIER, P. "Quelle démocratie dans l'Église?, em sua obra La morale sort de l'ombre, Desclée De Brouwer: Paris 2008, p. 275-283.
} 


\section{Em busca de um diálogo fracassado}

O Concílio foi consciente desta realidade e quis nos recordar dois aspectos da máxima importância para a situação atual. O primeiro é uma confissão explícita e humilde de que "as instituições, as leis, os modos de pensar e sentir herdados do passado, nem sempre parecem adaptar-se bem ao atual estado de coisas"17. O que significa que a verdade não foi descoberta de forma definitiva e se requer um esforço constante para conseguir um conhecimento progressivo. E em segundo lugar, se reconhece, também, consciente de sua limitação, que, apesar da revelação, não possui "sempre a imediata resposta a cada questão"18, e convida aos cristãos que se unam aos demais homens "na busca da verdade e na solução de tantos problemas que surgem na vida individual e social" ${ }^{19}$.

De modo que o Concílio não foi só uma tentativa de diálogo com o mundo, a cultura e as outras religiões, mas também buscou uma comunicação interna mais profunda que provesse "na mesma Igreja a estima mútua, reverência e concórdia, admitindo toda legítima diversidade para que se estabelecesse um colóquio cada vez mais frutuoso entre todos os que constituam um único povo de Deus, sejam pastores ou simples cristãos" ${ }^{20}$. Buscava uma nova forma de se compreender não a partir da hierarquia, mas a partir do povo de Deus que a constitui.

A partir de então, foram publicados excelentes documentos sobre o diálogo, como a primeira encíclica de Paulo VI, na qual se manifesta o desejo de "que o diálogo no interior da Igreja se faça mais intenso no que se refere a questões e a participantes, para que assim cresça a força vital (da Igreja)"21. O próprio Sínodo de 1985, convocado para analisar a aplicação do Concílio, não duvidou em afirmar que "a eclesiologia de comunhão é o conceito central nos documentos do Concílio". Há, sem dúvida, uma sensação generalizada de que semelhante tentativa ficou frustrada, sem chegar a se realizar em toda sua profundidade ${ }^{22}$.

\footnotetext{
${ }^{17}$ Constitución pastoral sobre la Iglesia en el mundo de hoy, n. 7.

${ }^{18}$ Ibid., n. 34.

${ }^{19} \mathrm{Ibid}$., n. 16. Cf. MADRIGAL, S. "El 'aggiornamento', clave teológica para la interpretación del Concílio". Sal Terrae, n. 98, p. 111-127, 2010.

${ }^{20}$ Ibid., n. 92. Cf. DIAS DA SILVA, J. "Gaudium et spes: um novo paradigma das relações Igreja-Mundo", em G. URIBARRI, (Org.). Teología y nueva evangelización. Madrid: Universidad Pontificia Comillas, 2005, p. 155-197. BOTELLA, V. "Balance de la recepción conciliar y futura del Vaticano II", Ciencia Tomista, v. 132, n. 3, p. 443-471, septiembrediciembre 2005. GONZÁLEZ-CARVAJAL, L. "Una nueva actitud de la Iglesia ante el mundo en la 'Gaudium et spes"'. Estudios eclesiásticos, v. 81, p. 421-433, 2006. MIRANDA, M. de França. "Igreja e sociedade na "Gaudium et spes" e sua incidência no Brasil". Revista Eclesiástica Brasileira, n. 66, p. 89-114, 2006.

${ }^{21}$ PABLO VI, Ecclesiam suam no ${ }^{2}$.

${ }^{22}$ MARTÍNEZ GORDO, J. "La renovación eclesial: del Vaticano II a nuestros días", Lumen 61 (2012) 35-75. VIDAL, M. “'Gaudium et spes' y Teología Moral. A los 50 años del Concilio Vaticano II". Moralia, n. 35, p. 103-153, 2012. AA. VV., "250 números desarrollando el proyecto del Concilio". Iglesia Viva, no ${ }^{0}$ 250, 2012.
} 
Em muitos ambientes se criou certa desilusão. A "neurose de paternalismo", que havia denunciado Häring há muito tempo ${ }^{23}$, não parece que haja desaparecido. Diante do desconcerto que alguns experimentam por causa do pluralismo existente, busca-se a união com o poder da autoridade e uma vigilância extrema sobre qualquer possível desvio. A docilidade que se consegue, nestas circunstâncias, não brota do respeito amoroso nem da convicção pessoal, mas do medo em sofrer as consequências. Nada há mais perigoso que sacralizar a norma para lhe dar maior ênfase; apresentála como patrimônio absoluto da tradição quando, muito, é fruto de pequenas tradições ${ }^{24}$.

No campo da práxis cristã, sobretudo, o recurso à autoridade de Deus nem sempre se faz possível, porque muitos dos problemas que nos afetam não se explicitam a partir da revelação. É verdade que o magistério goza de especiais garantias pela presença do Espírito, mas seu ensinamento concreto não está livre de uma justificação racional. A demanda deste esforço não supõe nenhuma rebeldia, senão um direito de que a conduta brote de uma convicção pessoal. O fato de que a doutrina da Igreja exija do crente uma atitude de docilidade e submissão, de acordo com a doutrina do Vaticano II, não supõe prescindir deste recurso pastoral, cada vez mais necessário. A autoridade tem muitos mecanismos para impor pela força seus critérios, mas assim só se consegue um silêncio temeroso, que não ajuda a formação de consciências convictas e responsáveis ${ }^{25}$.

Não é exagero afirmar que existe uma preocupação em insistir na unidade, mediante a exclusão de todo pluralismo, e promover a autoridade de Roma, cujo controle se impõe de múltiplas maneiras ${ }^{26}$. O fato é que as suspeitas

${ }^{23}$ HÄRING, B. "La ética teológica ante el III milenio del cristianismo". In: VIDAL, Marciano (Org.). Conceptos fundamentales de ética teológica, Trotta: Madrid. 1992, p. 19. Versão brasileira: VIDAL, Marciano. Ética teológica: conceitos fundamentais de teologia. Petrópolis: Vozes, 1999.

${ }^{24}$ Cf. o interessante artigo de SOTOMAYOR, M. "Historias, historia y condicionamiento histórico", Proyección, n. 40, p. 225-240, 1993. GONZÁLEZ FAUS, J. I. La autoridad de la verdad. Momentos oscuros del magisterio eclesiástico. Sal Terrae: Santander, 2006, oferece abundantes fatos históricos para compreender a mudança de certas tradições, inclusive dentro do ensino da Igreja.

${ }^{25}$ Ver o interessante artígo de MACCISE, C. "La violencia en la Iglesia". Testimonio, n. 200, p. 41-49, 2003, (resumo em Selecciones de Teología, n. 43, n. 170, p. 187-193, abriljunio 2004, onde analisa outras formas mais sutis de violência. E em TIERNEY, B. "Modelos históricos del papado". Concilium, n. 108, p. 207-218, 1975, como foram vividos historicamente. Versão brasileira: Concilium, Petrópolis, v. 108, p. 56-65, 1975.

${ }^{26}$ MARTÍNEZ GORDO, J. "El gobierno de la Iglesia: síntomas de un malestar", Surge, n. 62 , p. 443-465, 2004. BEINERT, W. "Diálogo y obediencia en la Iglesia", Selecciones de Teología, n. 39, p. 61-70 2000. RUIZ DE GOPEGUI, J. A. "O Concilio Vaticano II quarenta anos depois", Perspectiva Teológica, n. 37, p. 11-30, 2005. ARANA, M. J. "El diálogo en el interior de la Iglesia", Sal Terrae, v. 94, n. 1098, p. 143-154, 2006. TORRE DÍAZ, J. DE LA. "El magisterio moral de la Iglesia dentro de una eclesiología de comunión", Sal Terrae, v. 98, n. 145, p. 447-478, mayo 2010. CASTELLANOS FRANCO, N. "Otra manera de ser iglesia hoy es posible”. Selecciones de Teología, n. 50, p. 163-174, 2011. 
mútuas e as desconfianças profundas da parte da hierarquia e dos teólogos impedem qualquer tipo de diálogo que pudesse levar ao esclarecimento dos problemas. E é evidente que com esta dificuldade de comunicação, tenhamos que repartir a culpa com todos. Uma hierarquia sem diálogo com os fiéis, como acontece com frequência, é tão perigosa e pouco crível, como alguns fiéis que prescindem da hierarquia, como também acontece. Do mesmo modo, não é enriquecedor que, quando se fomenta algum tipo de encontro, se realize fundamentalmente com os da própria ideologia.

\section{Alguns dados significativos: colegialidade e magistério}

Esta situação, à qual me referi, manifesta-se em dois fatos concretos e significativos. A debilitação das Conferências Episcopais é um sinal que pretende evitar qualquer indício de disparidade. $\mathrm{Na}$ eclesiologia de comunhão, sublinhada pelo Concílio, apesar das reticências existentes, aparece com força a colegialidade de todos os bispos à frente de suas igrejas, presidida pelo bispo de Roma. A autoridade suprema da Igreja não seria só o Papa, senão todo colégio episcopal com e sob o romano pontífice. Fruto dessa nova eclesiologia, nasceram os sínodos dos bispos e as conferências episcopais. Muitos continuam acreditando que semelhante caminho ficou obstruído para retirar dele todas suas consequências por causa das cautelas posteriores que se deram na legislação.

Apesar de seu rechaço generalizado por parte de uma grande maioria ao projeto do documento ${ }^{27}$, a carta apostólica Apostolos suos concede à Santa Sé constituir as conferências, aprovar seus estatutos e controlar suas ações ${ }^{28}$. Por isso, "quando os bispos de um território exercem conjuntamente algumas funções pastorais... tal exercício, sem dúvida, não assume nunca a natureza colegial característica dos atos da ordem dos bispos enquanto sujeitos da suprema potestade sobre toda a Igreja" (n. 12). Também eles ficam submetidos ao ditame de Roma, inclusive naquelas questões onde não estão em jogo a fé, mas a prudência pastoral na orientação de seus fiéis. A Conferência é só uma manifestação do afeto colegial, mas sem força obrigatória para ensinar uma doutrina que não seja unânime e pre-

\footnotetext{
${ }^{27}$ NAUD, A. Dans le prolongement du Colloque de Salamanque. Le magistres des Conférences episcopales, Sciences et Esprit, n. 41, p. 93-114, 1989. É excelente artigo de ANTÓN, A. "El munus magisterii de las conferencias episcopales. Horizonte teológico y criterios de valoración", Gregorianum, n. 70, p. 741-778, 1989. SULLIVAN, F. A. "The Teaching Authority of Episcopal Conference". Theological Studies, n. 63, p. 472-493, 2002.

${ }^{28}$ GHIRLANDA, G. "Il M.p. Apostolos suos sulle Conferenze dei Vescovi”. Periodica, v. 88, p. 609-657, 1999. ÖRSY, L. "Las Conferencias episcopales y la fuerza del Espíritu. Razón y $\mathrm{Fe}$, n. 241, p. 153-164, 2000. PASTOR, F. A. " 'Authenticum epicoporum magisterium'. Las conferencias de obispos y el ejercicio de la 'potestas docendi' ". Periodica de Re Canonica, v. 89, p. 79-118, 2000. MARTÍNEZ GORDO, J. "La Curia Vaticana y las Conferencias episcopales: una complicada y deficiente relación", Lumen, v. 54, p. 43-70, 2005 .
} 
viamente aprovada pelo Papa. Não há dúvida de que o equilíbrio entre o primado romano e a colegialidade não está ainda totalmente resolvido.

Algo parecido teria que se dizer sobre o Sínodo dos bispos, que seria uma boa ocasião para estudar os problemas que afetam a Igreja. No entanto, a escolha do tema não é da competência deles e suas conclusões finais só têm um caráter apenas consultivo. Proposições apresentadas quase de uma maneira unânime não têm ressonância nas exortações posteriores. Alguns autores assinalaram que tudo isto manifesta certa desconfiança com relação ao colegiado episcopal ${ }^{29}$.

Um segundo sintoma também significativo é a maior força outorgada ao magistério ordinário da Igreja. Quando as Conferências Episcopais falaram da possibilidade de um dissentimento respeitoso, como no caso da Humanae Vitae, sob as devidas condições, é evidente que se produziu uma abertura perigosa. Existia o perigo de que estes ensinamentos, que não tinham um caráter dogmático, não tivessem maior eficácia na prática. O caminho mais eficaz que se buscou foi atribuir a alguns destes ensinamentos um caráter definitivo. Quando uma doutrina é proposta pelo Papa durante muito tempo, e em comunhão com os bispos, goza de uma força especial: ainda que não se tenha declarado como infalível, já não se poderá mudar no futuro por se tratar de algo definitivo.

Sei muito bem que para alguns autores esta mudança não estabelece dificuldades especiais, nem supõe alguma novidade, porque só se explicitou o que já estava presente na doutrina tradiciona ${ }^{30}$. No entanto, este não é o parecer de muitos outros que advertem sérias dúvidas nesta nova divisão, nas quais não vamos nos deter agora. O que é verdade e parece claro é que se trata de impor, com o peso do definitivo, doutrinas que não estavam claras na consciência do povo de Deus. As justificativas que foram dadas não parecem convincentes para muitos teólogos que veem, por este caminho, um desejo de reforçar a autoridade do magistério ${ }^{31}$.

${ }^{29}$ SESBOÜE, Bernard. "La réception officielle des énoncés de Vatican II sur l'épiscopat dans le document du Saint-Siège despuis le nouveau Code (1983-1999)". In: LEGRAND H.; THEOBALD, Christoph. Le ministères des évêques au Concile Vatican II et depuis. Hommage à Mgr. Guy Herbulot, Du Cerf: Paris, 2001, p. 148.

${ }^{30}$ Podemos ver, por exemplo, CARLOTTI, P. "Teologia morale e magistero", Salesianum, n. 63, p. 23-55, ianuarius-martius 2001. SALVATORI, D. "L'Ad tuemdam fidem e il c. 750: una novità in doctrina?. Periodica de Re Morali, n. 91, p. 423-458, 2002.

${ }^{31}$ ANTÓN, A. "I teologi davanti all'istruzione 'Donum veritatis", Gregorianum, n. 78, p. 223-265, 1997. CHIRON, J. F. "L'autorité du Magistrè infaillible lorsqu'il se prononce sur de verités non révelées. Dossier théologique", Revue d'Éthique et Théologie Morale. GAILLARDETZ, R. R. "El magisterio ordinario universal: problemas no resueltos", Selecciones de Teología, n. 43, n. 171, p. 171-186, julio-septiembre 2004. SESBOÜE, B. El magisterio a examen. Autoridad, verdad y magisterio en la Iglesia, Mensajero: Bilbao 2004. MOLINA, D. Evolución y vigencia de las condiciones de infalibilidad, Facultad de Teología: Granada 2005. HÜNERMANN, P. "Obligatoriedad de la doctrina eclesiástica y libertad de la Teología”. Selecciones de Teología, n. 47, p. 227-240, 2008. 


\section{A necessidade de uma evolução: para superar certo desencanto}

Ante uma situação como a que tentei expor, tal e como hoje muitos a vemos, não resulta estranho que bastantes crentes possam experimentar certos conflitos em sua consciência. Não me refiro agora aos católicos, cuja vinculação com a Igreja é demasiado periférica e superficial; sentem um claro desapego e indiferença frente aos ensinamentos da hierarquia; e, inclusive, manifestam sua agressividade e rechaço contra a instituição, cujo ensinamento creem que está o bastante desacreditado, como para outorgar-lhe a confiança que se lhes pede.

Penso, sobretudo, em muitas outras pessoas que desejam manter sua fidelidade e apreço por essa função do Magistério, pretendem manterem-se obedientes a seus ensinamentos, mas tampouco sabem como agir quando alguma doutrina é-lhes incompreensível. Sua própria formação científica os faz descobrir que a fundamentação de um ensinamento não é tão clara como se apresenta. Os problemas éticos são muitas vezes demasiado complexos, e até entre os próprios cientistas não existe unanimidade de critérios. Nestas situações é a obediência a única alternativa possível?

Não há dúvida de que, no campo da moral, somos muitos os que desejaríamos certa evolução em algumas das exigências éticas que se apresentam ao povo cristão. Não me refiro agora a nenhuma concretamente para não levantar discussões, mas o desejo está presente no coração de muitos fiéis ${ }^{32}$.

Qualquer pessoa que conheça um pouco a história da Igreja pode captar imediatamente como se tem dado a evolução em sua doutrina, às vezes, com retrocessos e vacilações. Impressionou-me um texto de Bento XVI, em um livro dedicado a seus alunos em 1967. Recolhendo uma narração parabólica de Kierkegaard, quando um palhaço teve que ir à aldeia para avisar de um fogo no circo e todo mundo pôs-se a rir e não acreditou em seu grito por auxílio, comenta: "uma imagem do teólogo a quem não se leva a sério, se veste como os atuantes de palhaço da idade média ou de qualquer outra época passada. Lá pode dizer o que quiser, leva sempre a etiqueta do papel que desempenha. E, ainda que se esforce por apresentarnos com toda seriedade, sabe-se de antemão o que é: um palhaço. Conhecese o que diz e se sabe também que suas ideias não têm nada a ver com a realidade. Pode-se escutá-lo confiado, sem temor ao perigo de ter que preo-

\footnotetext{
${ }^{32}$ BRACKLEY, Dean. Tendencias actuales de la Teología moral en América Latina. Revista Latinoamericana de Teología, San Salvador, v. 19, n. 55, p. 95-120, 2002. CUESTA ÁLVAREZ, B. Teología moral en camino: del Concilio Vaticano II a nuestros días. Ciencia Tomista, n. 132, p. 515-544, 2005. FRANCCA MIRANDA, M. de. O Concílio Vaticano II ou a Igreja em contínuo aggiornamento. Perspectiva Teológica, Belo Horizonte, n. 38, p. 2331-250. VIDAL, M. El malestar moral en la Iglesia. In: Orientaciones éticas para tiempos inciertos. Bilbao: Desclée De Brouwer, 2007, p. 15-32. CARRERA, D. Una moral para nuestro tiempo. Selecciones de Teología, n. 50, p. 299-318, 2011.
} 
cupar-se seriamente por algo. Sem dúvida alguma, nesta imagem pode-se contemplar a situação na qual se encontra o pensamento teológico atual"33.

A avaliação não deixa de ser demasiado dura, mas me parece muito objetiva e realista, sobretudo pela autoridade do que se atreveu a escrevê-la. É um toque de atenção para evitar aquelas apresentações que obscurecem ainda mais o rosto de Deus e o distanciam do mundo atual. Uma dificuldade que aumenta ainda mais, quando fazemos referência aos problemas éticos, que afetam mais de perto a vida das pessoas.

Quero dizer que a ética normativa, como conjunto de valores, não tem sido configurada de maneira definitiva e para sempre, mas está submetida também a um processo evolutivo. As mudanças culturais e científicas fazem com que nos aproximemos da realidade a partir de uma óptica diferente. Não no sentido de uma mudança constante, como se a moral fosse uma vareta nas mãos do vento que sopra, mas uma atitude de busca permanente para responder em cada situação, de forma mais humana e evangélica, aos problemas que se apresentam. A vista cansada que necessita distanciar-se dos objetos, para contemplá-los melhor, será um defeito orgânico, mas se converte em uma condição necessária para olhar com lucidez os acontecimentos da história. Esta evolução histórica tem que provocar necessariamente momentos de crise e vacilação, pois toda mudança rompe a estabilidade conseguida e supõe um desajuste entre o novo e a norma aceita anteriormente.

Manter-se plenamente fiéis aos critérios tradicionais significaria condenar para sempre qualquer nova experiência que não se atenha às normas anteriores. Aquelas nasceram para iluminar situações concretas de seu momento histórico, mas é possível que se considerem defasadas para orientar as novas possibilidades que se apresentam no decurso da história. Existe em muitos a crença ingênua de que a verdade já foi descoberta completamente, sem outra possibilidade para repetir o mesmo de maneira contínua.

A moral seria, então, uma ciência estática, anódina, incapaz de responder às interrogações atuais que se apresentam, pois a solução já foi buscada anteriormente. Mais ainda, chegaria a converter-se em uma força opressora para impedir qualquer evolução, como às vezes tem sido feito, e defender outras seguranças e interesses, que com frequência se escondem em algumas atitudes imobilistas e radicalmente conservadoras. Há fidelidades que não nascem para conservar um valor para defendê-lo contra o desgaste do tempo, mas pela inércia de um costume que já não tem sentido, ou pela obstinação narcisista e cômoda do que prefere a rotina, sem atreverse a recriar o passado.

${ }^{33}$ RATZINGER, Joseph. Introdución al cristianismo. Salamanca: Sígueme, 1976, p. 22. Versão brasileira: RATZINGER, Joseph. Introdução ao cristianismo: preleções sobre o símbolo apostólico com um novo ensaio introdutório. São Paulo: Loyola, 2005. 
Da mesma maneira a riqueza histórica e o patrimônio cultural das gerações anteriores não se podem sacrificar em favor de qualquer novidade. Como se os descobrimentos e esforços de nossos antepassados houvessem sido totalmente falsos e em nada pudessem ajudar-nos. Um trabalho e esforço que requerem diálogo e discernimento para encontrar o melhor para a pessoa humana, que se identifica também com a vontade de Deus. Mas mesmo que exista uma mentira que possa destruir o rico patrimônio herdado da tradição, também se faz presente com frequência, lamentavelmente, um espírito mentiroso que não quer abrir-se a uma verdade que se vai gestando. A opacidade, em ambos os casos, se converte em um impedimento para descobrir onde se encontra a luz que possa seguir iluminando.

\section{Os ensinamentos da história}

Se a mudança e a evolução são necessárias, para não cair em uma esclerose lamentável, ou para que nossa oferta não seja a de um paraíso - em frase de Ratzinger - do que a gente sorri e a que não se dá nenhuma credibilidade, a mensagem ética da Igreja necessita também, como tenho dito, de certa renovação. Quando a única alternativa na Igreja for repetir exclusivamente e ao pé da letra o que o magistério afirma, como hoje se volta a dizer e se quer impor, não pode existir nenhuma possibilidade de avanço. Antes que a autoridade oficial aprove uma nova orientação, essa ideia tem que se gestar antes em outros níveis.

A história demonstra como tais discrepâncias foram fecundas para o processo de uma doutrina. Basta recordar o que já ocorreu na Igreja no começo e meados do século anterior, sem analisar agora outras situações parecidas em tempos anteriores. Os novos avanços no campo da Escritura exigiram muito trabalho até que fossem integrados em sua doutrina. $\mathrm{O}$ mesmo que a renovação teológica, na década de 50, provocou outra série de condenações e proibições. Em ambas as reformas, bastantes crentes pagaram a ousadia de abrir novos caminhos: livros proibidos, teólogos afastados de suas cátedras ou condenados ao silêncio. No entanto, quando agora se leem os numerosos documentos publicados, naqueles anos, contra as novas contribuições bíblicas e teológicas, é inevitável um sorriso de benevolência. E alegra saber que, precisamente, os teólogos suspeitos e condenados foram os renovadores do Concílio Vaticano II, e até a própria Igreja reconheceu seus méritos e os serviços prestados com dignidades eclesiásticas. Graças ao sofrimento, paciência e fidelidade destes cristãos ameaçados, a própria Igreja acabou enriquecendo-se com seu trabalho.

E é que não supõe nenhum descrédito para a autoridade o reconhecer que seu carisma e função não se centram precisamente em ser agente de mudança, mas em manter a harmonia, coesão e unidade do grupo para evitar o perigo da desintegração. Por isso, como a tranquilidade definitiva nunca resulta possível - e seria, além disso, um sinal de que a vida languesce - 
é bom que brote de vez em quando o protesto, o inconformismo ou a contestação que impedem ancorar em uma etapa do caminho.

Qualquer pessoa que possua um pouco de perspectiva histórica, inclusive sobre a época mais recente, terá que admitir que os caminhos tenham sido com frequência fruto dos fatos consumados. O que no princípio se considerou um gesto de indisciplina ou desobediência, uma conduta própria de pessoas rebeldes e inobservantes, termina por impor-se mais tarde como algo normal e confirmado pela própria autoridade. Muitos santos e todos os revolucionários foram tidos como molestos, suspeitos e criticados pelas autoridades competentes, já que pareciam perigosos para os esquemas teológicos, culturais ou políticos do momento. Com o passar do tempo e a avaliação histórica só nos resta agora a colheita daquela semeadura que agradecemos, mas deixamos no esquecimento a dor, os conflitos e o esforço que supôs, quando foram condenados como traidores, iluminados, loucos ou equivocados.

Por isso, nem toda transgressão, quer dizer, avançar um pouco além dos limites, quando não está em perigo o depósito da fé - é algo condenável. É a lógica e inevitável tensão entre a autoridade, que procura defender a união e tenta mantê-la com a docilidade e obediência, e a nova força que desperta como uma ameaça perigosa, pois vem a romper o equilíbrio existente e a coesão conseguida. Todos estamos com medo. Alguns porque a mudança resulta traumática, incontrolada e o consideram uma traição. Outros, pela apatia e lentidão com que se realiza ${ }^{34}$.

Não é tampouco necessária nenhuma interpretação maniqueia, entre bons e maus, já que nessas situações de mudança existem muitas nebulosas para distinguir com clareza o que parece mais conveniente. Os responsáveis se sentem obrigados a defender o patrimônio recebido para que a evolução não se converta em um desastre. $\mathrm{E}$ o remédio mais eficaz, para evitar qualquer renovação, tem sido sempre o desprestígio e a condenação dos que vislumbravam melhores horizontes. Dessa maneira, enquanto são considerados como pecadores ou rebeldes diminui sua possível influência no ambiente e se vacinam os demais contra o perigo de contágio. Quando a transgressão desperta sentimentos de culpabilidade e arrependimento se confirma a coesão e a ordem estabelecida, mas, na medida em que tais sentimentos diminuem se facilita seu posterior não cumprimento e a ampliação de suas fronteiras ${ }^{35}$.

${ }^{34}$ Recomendo a leitura de GÓMEZ SERRANO, P. J. El miedo en la Iglesia hoy. Sal Terrae, Santander, v. 98, n. 1148, p. 695-709, septiembre 2010.

${ }_{35}$ Apesar dos anos passados, resultam ainda interessantes os artigos de FOUREZ, G. Transgression et morale: une problematique. Supplément, n. 35, p. 5-18, 1982 e D'HANEN. De la trace transgressive. Problèmes et apports d'une analyse historienne de la transgression, $i b .$, p. 31-40. 
Como, além disso, muitas transgressões terminam no fracasso e resultam estéreis, sua recordação se utiliza como argumento para legitimar a normativa vigente e impedir que outros se dirijam para novos caminhos. O que não se diz é que, em outras ocasiões, também resultaram positivas e serviram como ponto de partida para as mudanças posteriores. Então, quando a autoridade os confirma e, inclusive, quando recompensa e louva mais adiante os que censurou anteriormente, os mais tranquilos e observantes caminham já com boa consciência por veredas que outros abriram com uma desobediência fecunda e dolorosa.

\section{Crentes submissos e crentes inquietos}

Há gente boa que não tem dificuldade em submeter-se a tudo o que foi mandado, ainda que tenha que pagar o preço de uma submissão passiva. Nem tampouco nunca vai ser criticada. Terá, além do mais, ganhado o beneplácito da autoridade correspondente. Inclusive determinadas psicologias, incapazes de enfrentar qualquer tipo de dúvida ou incerteza, exigem, mais ou menos explicitamente, a firmeza do que manda para evitar qualquer angústia ou dúvida interior. Para estes a paciência e a tolerância, que hoje às vezes se têm com os inconformistas, não são nada mais que um sintoma de covardia e de um respeito humano inaceitável. As normas são feitas para serem cumpridas e nem sequer resulta válida qualquer interpretação que desvirtue sua eficácia. A crise eclesial é causada, sobretudo, por falta de uma autoridade que mande e imponha. O que alguns desejam na atualidade me recorda muito o que já se tinha pedido em tempos anteriores ${ }^{36}$.

Seria necessário reconhecer, inclusive, que a ideologia mais conservadora tem hoje lugar relevante. Se utilizarmos uma linguagem política - que aqui certamente não resulta a mais adequada - hoje diríamos que a leva a ganhar, sem representar a grande maioria. São os grupos que gozam de maior estima nos estamentos eclesiais e recebem os melhores elogios ${ }^{37}$.

Nosso Papa atual escrevia, faz alguns anos, quando fazia referência à atitude do cristão entre a liberdade do testemunho, que o faz lutar contra os

\footnotetext{
${ }^{36}$ Chamou-me a atenção a seguinte citação de La Civiltà Cattolica contra o catolicismo liberal do século XIX que, no melhor dos casos, alguém repetiria hoje com gosto: "Os princípios católicos não se modificam, nem porque os anos correm, nem porque se muda de país, nem por causa de novos descobrimentos, nem por razão de utilidade... Quem os aceita em sua plenitude e rigor é católico; o que duvida, se adapta aos tempos, transige, poderia dar-se a si mesmo, se quiser, o nome que queira, porém diante de Deus e da Igreja, é um rebelde e um traidor". Tomado de LABOA, J. M. Historia de la Iglesia Católica: edad contemporánea. Madrid: BAC, 1999, p. 82-83.

${ }^{37}$ LÓPEZ AZPITARTE, E. Esperanza que perdura en la vida de cristianos amenazados. CIAS (Argentina), n. 651, p. 415-426, 2002.
} 
fatos da Igreja, e a obediência silenciosa da aceitação: “No entanto, a verdadeira obediência não é a obediência dos aduladores..., que evitam todo choque e põem sua intangível comodidade acima de todas as coisas... O que a Igreja de hoje necessita (e de todos os tempos) não são panegiristas do existente, mas homens em quem a humildade e a obediência não sejam menores que a paixão pela verdade; homens que deem testemunho a despeito de todo desconhecimento e ataque; homens, em uma palavra, que amem a Igreja mais que a comunidade ${ }^{\prime \prime 38}$.

E estes crentes também existem. Gente que deseja buscar novos caminhos, que tem uma experiência de Deus, mas que não estão totalmente satisfeitos com algumas ofertas que se apresentam ao povo cristão. Seria lamentável que sua voz ficasse abafada pela força, como se não tivessem nenhuma contribuição a dar nos momentos atuais, ainda que pudessem resultar também incômodos.

Não entro agora em todos os problemas que estão implicados na recepção da doutrina por parte dos fiéis; nem sobre o que diz o Direito Canônico sobre esta prática que tem e suas experiências históricas; o que afirma mais recentemente um documento romano: "Nem todas as ideias que circulam no seio do Povo de Deus resultam coerentes com a fé, mais ainda quando podem sofrer facilmente a influência de uma opinião pública difundida pelos atuais meios de comunicação" ${ }^{\prime 39}$. Porém nem tudo pode vir de má vontade ou da rebeldia interior. Quando um numeroso grupo de crentes comprometidos com sua fé, que amam a Igreja, sinceros em suas reflexões experimentam sérias dificuldades em algumas posições éticas, devem estar em jogo verdades fundamentais ${ }^{40}$.

Todos estão de acordo em que a sociologia não tem força normativa alguma, pois constata simplesmente a realidade, a margem dos valores que encerra. Nem tampouco o bem perde seu caráter universal e obrigatório porque a maioria das pessoas não querem vivê-lo. No entanto, ajuda a revelar a existência de outras convicções e motivos mais ocultos, que explicam os caminhos de conduta acontecidos ou os que se poderia realizar no futuro próximo. Se os fatos por si mesmos não têm força moral para impor uma conduta, se podem enfrentar-nos com uma realidade oculta que justificaria um reconhecimento mais profundo dos dados anteriores. $\mathrm{O}$

${ }^{38}$ RATZINGER, J. El nuevo pueblo de Dios. Barcelona: Herder, 1972, p. 292-293. Pouco mais adiante continua: Mas não se deverá reprová-la (a Igreja) que, por excesso de solicitude, declara demasiado, regramento demasiado e que tantas normas e regulamentos têm contribuído para abandonar ao século a incredulidade, que não a salvá-lo dela...?, p. 294-295.

${ }^{39}$ CONGREGAÇÃO PARA A DOUTRINA DA FÉ. Instrucción sobre la vocación eclesial del teólogos, n. 35.

${ }^{40}$ Remeto-me de novo ao livro de J. I. GONZÁLEZ FAUS, Op. cit. (nota 23). 
importante não é a pura facticidade, mas o dinamismo interno e razoável que os impulsiona. Qualquer um que conheça a história da Igreja sabe a influência que têm trazido estes movimentos ${ }^{41}$.

\section{Ademais do diálogo: Sinceridade diante de Deus e a própria consciência}

O único caminho, em uma situação como esta é um diálogo profundo, sincero e respeitoso. Recordo as esplêndidas palavras do cardeal Woytila, não publicadas, em uma das sessões do Vaticano II: "Não pode existir diálogo se a Igreja se coloca acima do mundo e não no mundo. A Igreja deve apresentar-se ao mundo não como docente, pedindo só obediência e falando autoritariamente, mas antes deve buscar junto com o mundo como encontrar a verdade: porque se não, o seu será um solilóquio".

Não se trata de ver quem vence. A autoridade da Igreja tem sempre uma prevalência. Toda riqueza histórica e o patrimônio cultural das gerações anteriores não se podem dilapidar em favor de qualquer novidade, como já dissemos. O respeito à tradição está presente em todas as culturas, pois a experiência acumulada poupa muitos esforços e facilita o avanço com maiores probabilidades de êxito. São séculos de história que oferecem uma profunda sabedoria para não partir nunca do zero e que seria absurdo esquecer para começar de novo como se nada houvesse aprendido. A rebeldia e o inconformismo têm suas raízes obscuras, que tampouco interessa muitas vezes despertar. Isto justifica a defesa da verdade transmitida ao largo das gerações para que nenhuma novidade falsa a ponha em perigo.

Mas é possível também que, depois de um esforço sincero e da melhor boa vontade, haja cristãos que não consigam compreender alguma exigência concreta, como reconhece a Conferência Episcopal Alemã: "Cabe a possibilidade de que alguns cristãos, apesar de seu esforço sincero por aceitar

\footnotetext{
${ }^{41}$ Sobre o tema pode ver-se: CONGAR, Y. La recéption comme réalité ecclésiologique. Revue de Sciences Philosofique et Théologique, n. 56, p. 369-403. VORGRIMLER, H. Del 'sensus fidei' al 'concensus fidelium', Concilium, 200, p. 5-19, 1985. Versão brasileira: Concilium, Petrópolis, v. 200, n. 4, p. 6-15, 1985. VITALI, D. Sensus fidelium. Una funzione ecclesiale di intelligenza della fede. Brescia: Morceliana, 1993. LANNE, E. La notion ecclésiologique de réception. Revue Théologique de Louvain n. 25, p. 30-45, 1994. ANTÓN, A. La recepción en la Iglesia y eclesiología. Gregorianum n. 77, p. 57-95 e 437469, 1996. LEGRAND, H.; MANZANARES, J.; GARCÍA Y GARCÍA, A. (Org.). La recepción y la comunión entre las Iglesias; actas del Coloquio Internacional. Salamanca: Universidad Pontificia, 1997. VITALI, D. Universitas fidelium in credendo falli nequit (LG 12). O 'sensus fidelium' al Concilio Vaticano II. Gregorianum, n. 86, p. 607-628, 2005. (Temática desse número): Leer el Magisterio y la Tradición. Sal Terrae, Santander, v. 97, n. 1139, 2009 .
} 
determinadas afirmações do magistério, tenham dificuldades sérias para despejar suas dúvidas ${ }^{42}$. A Igreja não tem estado sempre livre de erros, que devem ser corrigidos com o tempo, ainda que fosse um lamentável equívoco deduzir daí que se engana ordinariamente em suas manifestações. Como os próprios bispos alemães afirmam na continuação, quem dissente terá que pensar ante Deus e ante sua própria consciência se está capacitado para tomar uma decisão tão importante.

Hoje existe também, como dizíamos anteriormente, muita desafeição e agressividade contra os ensinamentos da Igreja. Ninguém poderá compreender uma pessoa ou uma instituição se não experimenta por elas um sentimento de afeto. $\mathrm{O}$ carinho autêntico é o único que possibilita a proximidade e compreensão, mas tampouco cega para ver as sombras e limitações. Por isso, enquanto o dissentimento não brota de um amor e compromisso profundo não será digno de crédito. Parece-me que é o critério mais fundamental para distinguir quem se sente movido pelo Espírito e quem está inspirado por outras palomas perigosas que, às vezes, se confundem com ele. Como diria São Paulo, quando nos fala do discernimento, é a autenticidade da práxis a que determina quem dinamiza por dentro ${ }^{43}$.

\section{Epílogo}

Quem vê nestas linhas um elogio incondicionado à desobediência e rebeldia é porque acrescenta algo mais ao que está dito. Ninguém busca o protesto nem o rechaço frente aos ensinamentos da Igreja, como se a verdade fosse patrimônio dos insubmissos. Porém também a autoridade se equivoca e quando o súdito expõe, demanda, critica e se rebela não está sempre impulsionado pelo mau espírito. Sem obediência não há humanismo, ordem e tranquilidade, mas sem transgressão tampouco existirá avanço ${ }^{44}$. O difícil nesses momentos é discernir quem se aproxima mais da verdade, quem a busca com maior afinco, disposto a jogar-se todo por defendê-la. São circunstâncias que ainda requerem um tempo de clarificação, durante o qual o conflito se faz inevitável, mas enriquecedor para todos. Se o silêncio, a submissão e a paciência seguem sendo valores importantes para o cristão, tampouco se pode condená-lo em todos os casos,

\footnotetext{
${ }^{42}$ Catecismo Católico para adultos II. Madrid: BAC, 1998, p. 96.

${ }^{43}$ MARTÍNEZ, M. Discernimiento personal y comunitário: necesidad, claves y ejercicio. Madrid: San Pablo, 2001. MEGUERDITCHIAN, N. Vivir un discernimiento espiritual: algunas indicaciones psicológicas. Madrid: San Pablo, 2001. FÉDRY, J. Discernir según Dios: el método de Ignacio de Loyola. Santander: Sal Terrae, 2001. AA.VV. La práctica del discernimiento. Ayudas para no desnortearse. Sal Terrae, Santander, n. 100, p. 393448.

${ }^{44}$ LÓPEZ AZPITARTE, E. De la obediencia a la trangresión. Razón y Fe n. 233, p. 579591, jun. 1996. GUILLEBAND, J. C. Entre limite et transgression. Esprit, n. 297, p. 121138.
} 
quando se faz molesto e conflitivo. Por isso, me daria pena também que de nossa comunidade eclesial desaparecessem os crentes e teólogos incômodos que nos impulsionam a caminhar para diante ${ }^{45}$.

Tradução: Jackson Alves de Carvalho

Eduardo López Azpitarte, padre jesuíta, licenciado em Filosofia e doutor em Teologia. Professor emérito da Faculdade de Teologia de Granada, Espanha.

Endereço: Facultad de Teología de Granada

Profesor Vicente Callao, 15

(Campus Universitario de Cartuja)

Granada - España

${ }^{45}$ Recomendo a leitura de VITORIA, J. Los conflitos en la Iglesia. Santander: Sal Terrae, n. 80, n. 951, p. 775-784, noviembre 1992. LABOA, J. M. Los cristianos incómodos. Santander: Sal Terrae, n. 78, p. 291-302, abril 1990 e Teólogos bajo sospecha. Santander: Sal Terrae, n. 84 p. 107-116, 1996. HÄRING, B. La disidencia en la Iglesia. Éxodo, n. 36, p. 47-53, 1996. PEREA, J. Disentir para reformar la Iglesia. Iglesia Viva, n. 245, p. 61-100, ener./mar. 2011.

372 Perspectiva Teológica, Belo Horizonte, Ano 44, Número 124, p. 353-372, Set/Dez 2012 